\title{
Foliar indices for carrot crop using the compositional nutrient diagnosis method ${ }^{1}$
}

\author{
Frederico Dellano Souza Silva², Natalia Oliveira Silva ${ }^{3}$, \\ Thaísa Fernanda Oliveira ${ }^{2}$, Marcelo Rodrigues dos Reis ${ }^{4}$, Leonardo Angelo de Aquino ${ }^{4}$
}

\section{ABSTRACT}

Carrot has a high yield potential, which requires an adequate and adaptable nutritional management, according to the needs and demands of each crop. Foliar diagnosis is a tool for adjustment and constant improvement of crop fertilization programs. This study aimed to determine leaf indices and reference values using the compositional nutrient diagnosis (CND) method, at three phenological stages of carrot crops [40 and 70 days after sowing (DAS) and at harvest]. In order to calculate the CND method, a database was created with leaf contents of the nutrients $\mathrm{N}, \mathrm{P}, \mathrm{K}, \mathrm{Ca}, \mathrm{Mg}, \mathrm{S}, \mathrm{B}, \mathrm{Cu}, \mathrm{Mn}$ and $\mathrm{Zn}$ and root yields, in commercial carrot crops. The nutrient limitation order was generated according to the fertilization response potential. At $70 \mathrm{DAS}$ and at harvest, $\mathrm{Mg}$ and $\mathrm{Mn}$ were the most limiting nutrients by deficiency, while $\mathrm{Zn}$ was the most limiting by excess at 70 DAS, and $\mathrm{P}$ and $\mathrm{Ca}$ were the most limiting by excess at harvest. The results indicate that the foliar diagnosis performed with the CND method is only effective for the correction of nutritional disturbances in subsequent crops.

KEYWORDS: Daucus carota L.; nutrient limitation; fertilization response potential.

\section{INTRODUCTION}

Concerning olericulture, carrots (Daucus carota L.) stand out for their nutritional and economic importance in Brazil, with an average yield of $31 \mathrm{tha}^{-1}$ in the 2014 crop season (ABH 2015). The region of Alto Paranaíba, Minas Gerais state, Brazil, has a great importance in the national carrot production, with crop yields superior to the national average, due to local factors (climate, soil and crop management),

\section{RESUMO}

Índices foliares na cultura da cenoura pelo método de diagnose da composição nutricional

A cenoura é uma cultura com potencial de alto rendimento, o qual requer manejo nutricional adequado e ajustável, com base nas necessidades e demandas de cada safra. A diagnose foliar é ferramenta para ajuste e constante aprimoramento de programas de adubação das culturas. Objetivou-se determinar índices diagnósticos foliares e valores de referência pelo método de diagnose da composição nutricional (CND), para três fases fenológicas da cultura da cenoura [40 e 70 dias após a semeadura (DAS) e na colheita]. Para o cálculo do método CND, foi criado um banco de dados com teores foliares dos nutrientes $\mathrm{N}, \mathrm{P}, \mathrm{K}, \mathrm{Ca}, \mathrm{Mg}, \mathrm{S}, \mathrm{B}, \mathrm{Cu}$, $\mathrm{Mn}$ e $\mathrm{Zn}$ e da produtividade de raízes, em cultivos comerciais de cenoura. A ordem de limitação nutricional foi gerada em função do potencial de resposta à adubação. Aos 70 DAS e na colheita, o Mg e o Mn foram os nutrientes mais limitantes por deficiência, enquanto o $\mathrm{Zn}$ foi o mais limitante por excesso aos 70 DAS, e P e Ca os mais limitantes por excesso na colheita. Os resultados indicam que a diagnose foliar pelo método CND apenas mostra-se efetiva na correção de distúrbios nutricionais nas safras posteriores.

PALAVRAS-CHAVE: Daucus carota L.; limitação nutricional; potencial de resposta à adubação.

surpassing $120 \mathrm{t} \mathrm{ha}^{-1}$ in the 2014 crop season (Dezordi et al. 2015).

Due to their high economic value, carrots require a precise nutrient management. Therefore, it is necessary to identify their nutrient demands, in order to define the appropriate amount of nutrients to be applied via fertilizers, with the aim of improving the plant performance, thus increasing the economic return and minimizing risks of nutrient losses in the system (Singh et al. 2012, Dezordi et al. 2015).

1. Manuscript received in Jun./2017 and accepted for publication in Dec./2017 (http://dx.doi.org/10.1590/1983-40632017v4747584).

2. Universidade Federal de Lavras, Departamento de Agricultura, Lavras, MG, Brasil.E-mails: fred_dss@hotmail.com, thaisafernanda135@gmail.com.

3. Universidade Federal do Vale do Jequitinhonha e Mucuri, Departamento de Agronomia, Diamantina, MG, Brasil. E-mail: nataliasilva.13@hotmail.com.

4. Universidade Federal de Viçosa, Instituto de Ciências Agrárias, Rio Paranaíba, MG, Brasil. E-mails: marceloreis@ufv.br, leonardo.aquino@ufv.br. 
Diagnostic indices obtained by leaf analysis have gained more importance in the last two decades (Parent 2011). These have been defined in crop fields whose production factors, whether nutritional or not, were maintained at non-limiting levels. For a greater reliability of the nutrient diagnosis, the edaphic and climatic and growing conditions of the crop to be diagnosed and the conditions in which these indices were established should be similar (Urano et al. 2007).

The nutritional diagnosis in the harvest phase allows correcting the fertilization program only in subsequent crops (Dezordi et al. 2016). However, an early diagnosis can be carried out by developing compositional nutrient diagnosis (CND) norms that are specific to the sampled period (Tomio et al. 2015). The possibility of performing an early diagnosis in carrot crops has already been demonstrated by using the DRIS method (Gonçalves et al. 2017).

The CND method, developed by Parent \& Dafir (1992), takes into account all possible nutrient interactions simultaneously occurring among the nutrients under diagnosis. The method generates a high degree of agreement in the nutrient diagnoses and is recommended when nutrient concentration and dilution effects are observed (Partelli et al. 2014). The CND method has been proposed for nutrient diagnosis in crops such as soybean (Urano et al. 2007), cotton (Serra et al. 2010), sweet orange (Camacho et al. 2012), sugar cane (Santos et al. 2013), common bean (Partelli et al. 2014) and carrot (Dezordi et al. 2016). However, diagnostic indices and reference values at different phenological stages of high-yield carrot crops have not been established yet.

The ranges for nutrient contents obtained with the CND method have lower amplitudes than those observed with other methods, such as mathematical chance (Wadt et al. 2013). It may be therefore inferred that this method presents a greater confidence, with less variability of soil, climate and yield potential conditions, as long as it meets the assumptions of high information and variation volumes (Camacho et al. 2012).

This study aimed to determine foliar diagnostic indices and reference values using the CND method at three phenological stages of carrot crops, as well as analyzing the viability of early nutrient diagnosis using this method.

\section{MATERIAL AND METHODS}

For the CND calculation, carrot leaf and root samples were collected to create a database containing the nutrient values of $\mathrm{N}, \mathrm{P}, \mathrm{K}, \mathrm{Ca}, \mathrm{Mg}, \mathrm{S}, \mathrm{B}, \mathrm{Cu}, \mathrm{Mn}$ and $\mathrm{Zn}$, in addition to carrot root yields, in commercial crops of the Alto Paranaíba region. The levels of Fe showed high contents and far above the usual values described in the literature. This was probably due to contamination of leaf samples by soil residue, which is rich in Fe oxides (Farias et al. 2009). Fe contents out of the usual values for this nutrient may interfere with the diagnostic indices of other nutrients. For this reason, the Fe content was not included in the database used to generate the diagnostic indices in this study. Leaf samplings were carried out in the years 2012 and 2013. The carrot crop fields were located at an altitude of approximately 1,100 m, where the Cwa climate predominates, according to the KöppenGeiger classification (Kottek et al. 2006). The soils in the region can be classified as Oxisols and have a very clayey texture (USA 2014), whose chemical attributes are shown in Table 1.

For leaf diagnosis, a pair of young leaves was collected at 40 DAS (stage 1) and 70 DAS (stage 2), and from all carrot shoots at harvest time. Stage 1 was defined based on full primary growth (root length growth) and root mean growth (diameter growth) (Marouelli et al. 2007). Phase 2 was determined when carrots were $1.5-1.6 \mathrm{~cm}$ in root collar diameter, at which time crops show a strong accumulation of dry matter and maximum absorption of nutrients (Cecílio Filho \& Peixoto 2013). The samples consisted of 210 plots at harvest time, 144 plots at the stage 1 and 176 plots at the stage 2, with plot areas ranging 2-15 ha, totaling 530 plots.

The main cultivars sampled in the summer (average cycle of 105 days) were 'Juliana' and 'Poliana', while, in the winter (average cycle of 125 days), the prominent ones were 'Baltimore', 'Belgrado', 'Maestro', 'Músico', 'Nancy', 'Nandrim' and 'Soprano'. The average amounts of $\mathrm{N}, \mathrm{P}_{2} \mathrm{O}_{5}$ and $\mathrm{K}_{2} \mathrm{O}$ used were $118 \mathrm{~kg} \mathrm{ha}^{-1}, 650 \mathrm{~kg} \mathrm{ha}^{-1}$ and $398 \mathrm{~kg} \mathrm{ha}^{-1}$, respectively. Urea and ammonium sulphate were the main sources of $\mathrm{N}$, single superphosphate and monoammonium phosphate of $\mathrm{P}$ and $\mathrm{KCl}$ of $\mathrm{K}$. Phosphate fertilizer was fully applied at sowing and incorporated into the soil, whereas $\mathrm{N}$ and $\mathrm{K}_{2} \mathrm{O}$ were applied at sowing and plotted under a covered structure. $\mathrm{N}$ was applied in the first and second thirds 
Table 1. Averages and standard deviation of soil chemical attributes $(0-20 \mathrm{~cm}$ depth) in the plots sampled during 2012 and 2013.

\begin{tabular}{|c|c|c|c|c|}
\hline Attribute & Unit & Extractor/Method & Mean & Standard deviation \\
\hline $\mathrm{pH}$ & - & $\mathrm{H}_{2} \mathrm{O}$ & 6.3 & 0.3 \\
\hline Organic carbon & dag $\mathrm{kg}^{-1}$ & $\mathrm{~K}_{2} \mathrm{Cr}_{2} \mathrm{O}_{7} /$ Walkley-Black & 2.0 & 0.3 \\
\hline $\mathrm{P}$ - remaining & $\mathrm{mg} \mathrm{L}^{-1}$ & - & 10.6 & 3.2 \\
\hline Phosphorus (P) & $\mathrm{mg} \mathrm{dm}{ }^{-3}$ & Mehlich-1 & 28.0 & 15.1 \\
\hline Potassium $\left(\mathrm{K}^{+}\right)$ & $\mathrm{mmol}_{\mathrm{c}} \mathrm{dm}^{-3}$ & Mehlich-1 & 3.1 & 0.8 \\
\hline Calcium $\left(\mathrm{Ca}^{2+}\right)$ & $\mathrm{mmol}_{\mathrm{c}} \mathrm{dm}^{-3}$ & $\mathrm{KCl}$ & 33.9 & 5.8 \\
\hline Magnesium $\left(\mathrm{Mg}^{2+}\right)$ & $\mathrm{mmol}_{\mathrm{c}} \mathrm{dm}^{-3}$ & $\mathrm{KCl}$ & 10.7 & 3.0 \\
\hline Sulfur $\left(\mathrm{SO}_{4}^{2-}\right)$ & $\mathrm{mg} \mathrm{dm}{ }^{-3}$ & $\mathrm{Ca}\left(\mathrm{H}_{2} \mathrm{PO}_{4}\right)_{2} \mathrm{H}_{2} \mathrm{O}$ in $\mathrm{AcOH}$ & 7.5 & 4.5 \\
\hline $\mathrm{CEC}(\mathrm{T})$ & $\mathrm{mmol}_{\mathrm{c}} \mathrm{dm}^{-3}$ & - & 82.3 & 8.2 \\
\hline Boron (B) & $\mathrm{mg} \mathrm{dm}{ }^{-3}$ & Warm water & 0.52 & 0.21 \\
\hline Copper $(\mathrm{Cu})$ & $\mathrm{mg} \mathrm{dm}{ }^{-3}$ & Mehlich-1 & 2.5 & 1.4 \\
\hline Iron $(\mathrm{Fe})$ & $\mathrm{mg} \mathrm{dm}{ }^{-3}$ & Mehlich-1 & 38.0 & 12.2 \\
\hline Manganese (Mn) & $\mathrm{mg} \mathrm{dm}{ }^{-3}$ & Mehlich-1 & 3.2 & 2.3 \\
\hline $\operatorname{Zinc}(\mathrm{Zn})$ & $\mathrm{mg} \mathrm{dm}^{-3}$ & Mehlich-1 & 6.8 & 3.0 \\
\hline
\end{tabular}

of the cycle. As for K, four to six applications were carried out along the cycle, as a usual practice in the region. The highest number of applications occurred in plots with lower $\mathrm{K}$ fertility and in long-cycle carrots.

After collection, the leaf samples were dried in a forced-air oven at $70^{\circ} \mathrm{C}$, for $72 \mathrm{~h}$. The leaves were then ground in a Wiley mill to pass a $1.27-\mathrm{mm}$ sieve. The nutrient contents were determined according to Malavolta et al. (1997).

To establish the CND norms, the population was divided into two classes, based on yield, which were defined according to the average yield plus $2 / 3$ of the standard deviation of this variable. The subpopulation showing the highest yield, considered nutritionally balanced, was the reference population, and was used to establish the comparison standards.

At the stage 1, of the 144 plots sampled, 31 $(21.5 \%)$ formed the reference population. At the stage 2, the reference class consisted of $50(28.4 \%)$ of the 176 sampled plots. At harvest, the reference population consisted of 64 (30.5\%) of the 210 sampled plots. The limit yields of the low and high yield classes (reference class) for the leaves collected at the stages 1 and 2 and at harvest time were 93.1 $\mathrm{t} \mathrm{ha}^{-1}, 90.6 \mathrm{t} \mathrm{ha}^{-1}$ and $87.8 \mathrm{t} \mathrm{ha}^{-1}$, respectively.

First or second order linear models were adjusted to describe the relationship between nutrient content and CND indices, in the reference population.

The CND values were obtained through the geometric mean of the nutrient contents for each sample (Parent 2011), and then the value of the multinutrient variable $\left(\mathrm{V}_{\mathrm{A}}\right)$ was determined according to the following expression: $V_{A}=\ln (X / G)$, where
$\mathrm{V}_{\mathrm{A}}$ is the value of the multivariate relationship between the evaluated nutrient content $(\mathrm{X})$ and the geometric mean of these contents $(\mathrm{G})$, obtained by the expression: $\mathrm{G}=(\mathrm{N} \times \mathrm{P} \times \mathrm{K} \times \mathrm{Ca} \times \mathrm{Mg} \times \mathrm{S} \times$ $\mathrm{B} \times \mathrm{Cu} \times \mathrm{Mn} \times \mathrm{Zn} \times \mathrm{R})^{(1 / n)}$. In this expression, $\mathrm{R}($ dry matter content of the sample, excluding the nutrients) is calculated by the difference between 100 and the sum of nutrient contents of the leaves: $\mathrm{R}=100-(\mathrm{N}+$ $\mathrm{P}+\mathrm{K}+\mathrm{Ca}+\mathrm{Mg}+\mathrm{S}+\mathrm{B}+\mathrm{Cu}+\mathrm{Mn}+\mathrm{Zn})$. With the $\mathrm{V}_{\mathrm{A}}$ values of each sample, the arithmetic mean $\left(\mathrm{V}_{\mathrm{A}}{ }^{*}\right)$ and the standard deviation $\left(\mathrm{S}_{\mathrm{A}}\right)$ were calculated for the sampled stages. $\mathrm{CND}\left(\mathrm{I}_{\mathrm{A}}\right)$ indices were calculated as suggested by Parent (2011): $\mathrm{I}_{\mathrm{A}}=\left(\mathrm{V}_{\mathrm{A}}-\mathrm{V}_{\mathrm{A}} * / \mathrm{S}_{\mathrm{A}}\right)$.

The CND indices for the nutrients of each sample, at each evaluated developmental stage, were the nutritional balance index (NBI), which, divided by the number of nutrients evaluated, consists of the mean NBI (mNBI). The CND indices were interpreted based on the criterion of fertilization response potential (FRP) (Wadt 2005).

To generate the order of nutrient limitation according to the fertilization response potential, the plots were divided into five groups: positive, positive or zero, zero, negative or zero, and negative (Wadt et al. 1998). Subsequently, the frequency of plots grouped in the classes with positive and positive or zero response was calculated for each nutrient. In these fertilization response classes, the nutrient can be considered as 'limiting by deficiency' for the crop. The order of nutrient limitation by deficiency was determined by organizing the nutrients at a decreasing order, by the frequency of limiting plots. 
For the nutritional status classifications, the plots were grouped into three classes for each nutrient: a) limiting by deficiency (LD), i.e., nutrients with negative CND index and higher (in module) than the $\mathrm{mNBI}$; b) limiting by excess (LE), i.e., nutrients with positive CND index and higher (in module) than the mNBI; c) non-limiting (NL), i.e., nutrients with lower CND index (in module) than the mNBI. The classifications were obtained by two different methods: based on the optimal range of leaf contents and on the fertilization response potential.

In relation to the optimal range method, plots with leaf contents below or above the range limits were classified as LD or LE, respectively. When the content was within the range, the nutrient was considered NL for the plot. For the response potential, the plots with positive and positive or zero response were classified as LD for the respective nutrient. The plots with zero response were classified as NL and, for the other fertilization response classes (negative and negative or zero), the plots were grouped in the LE class (Urano et al. 2006). The frequency of plots and the average yield of each class (LD, NL and LE) for all nutrients were presented in both classification methods (optimal range or fertilization response potential).

The t-test was performed to compare the average yields of the LD and LE classes with that of the NL class. Reference values were determined using the Microsoft Excel ${ }^{\circledR}$ software (Microsoft Corporation). Regression equations (linear and quadratic) were adjusted between leaf nutrient contents (the dependent variable) and CND indices (independent variables). The parameters of the adjusted equations were analyzed in order to test their significance by the t-test at $5 \%$, using the SAS software version 8.2 (SAS Institute 1999).

\section{RESULTS AND DISCUSSION}

The mathematical models adjusted between the CND indices and the leaf contents in the reference population were not significant at the stage 1 for $\mathrm{P}$, $\mathrm{K}, \mathrm{S}$; at the stage 2 for $\mathrm{N}, \mathrm{K}, \mathrm{Mg}, \mathrm{S}$; and at harvest time for $\mathrm{S}$ (Table 2). At the stage 2, all the cationic micronutrients obtained better adjustments with decreasing quadratic equations, whereas, for the other nutrients, the increasing linear equations were more convenient.

There was, in general, little agreement between the values published in the literature (Malavolta et al. 1997, Hanlon \& Hochmuth 2009) and the optimal content and optimal range determined by the CND method (Table 3). In the literature, with the exception of $\mathrm{Mg}$, there is a tendency for the values of the stage 1 to be higher than those found using the CND method. For the stage 2 and at harvest time, the optimal contents and optimal ranges found by the CND were higher than those published in the literature for all nutrients. In general, this lack of agreement between the literature and the values obtained in the present study may be explained by the differences in the cultivation of these crops, such as soil type. Moreover, the values published in the literature are out of date, given that they take into account lower yields, instead of the current high-yield crops (Dezordi et al. 2016).

The optimal content and optimal range values for the shoot nutrient concentrations calculated by the CND method varied according to the sampling times (Table 3). The optimal contents of $\mathrm{N}$ and $\mathrm{P}$ decreased between the sampling times. This may be explained by the increase of the shoot dry matter and the greater allocation of these nutrients in the roots, in relation to the shoot (Cecílio Filho \& Peixoto 2013, Aquino et al. 2015). In rice, a content reduction was observed for those nutrients, attributed to the dry matter dilution, due to the intense tillering that increased the plant dry matter during the studied period (Fageria et al. 2011). In carrots, $\mathrm{P}$ accumulates in greater proportions in the roots from 60 DAS (Dezordi 2014).

Despite being more accumulated in the roots (Dezordi et al. 2015), K showed an increase in the leaf content at harvest time. This may be explained by the fact that high yields of carrot crops depend on $\mathrm{K}$ levels sufficient to maintain a high leaf content, even though the partition of this nutrient to the roots is greater (Aquino et al. 2015, Gonçalves et al. 2017). A high leaf $\mathrm{K}$ is required to maintain high photosynthesis rates (which are necessary for high yields), as this nutrient regulates the mechanism of stomatal opening and closing. At harvest time, the high amount of accumulated $\mathrm{K}$ may be attributed to the greater demand of $\mathrm{K}$, in relation to the other nutrients, for species accumulating reserves in underground organs (Cecílio Filho \& Peixoto 2013).

Mn was the most limiting nutrient by the fertilization response potential method at the stage 1 and at harvest time, while $\mathrm{Cu}$ and $\mathrm{Ca}$ were the most limiting nutrients at the stage 2 (Table 4). Mn 
deficiency may be related to the low content of it in the soil (Table 1), high $\mathrm{pH}$ and large applications of $\mathrm{P}$ to the crop. In addition to Mn, limitations of $\mathrm{Cu}$ and $\mathrm{Zn}$ at the stage 1 are also significant, with Mn deficiency persisting until the end of the cycle. The deficiency of these nutrients, in addition to the relation with the soil $\mathrm{pH}$, may be related to the lower volume of soil explored by the very young plants at the stage 1 . The cationic micronutrients are transported in the soil mainly by diffusive flow (Pegoraro et al. 2006). Root growth reduces the transport distance of nutrients and facilitates a greater diffusive flow. Root growth over the cycle may reduce the degree of deficiency, as observed for $\mathrm{Cu}$ and $\mathrm{Zn}$, whose early-stage deficiency did not persist until harvest time (Table 4).

Table 2. CND norm (mean and standard deviation) of the multinutrient variables (Vi) and the geometric mean of the nutrient composition $(\mathrm{G})$, mathematical model, amplitude of the indices and coefficient of determination of the regressions adjusted to describe the leaf contents of carrot shoots, as a function of the CND index, in each sampled stage, for the reference population.

\begin{tabular}{|c|c|c|c|c|c|}
\hline \multirow{2}{*}{ Variable } & \multirow{2}{*}{ Mean } & \multirow{2}{*}{ Standard deviation } & \multicolumn{3}{|l|}{ Stage 1} \\
\hline & & & Mathematical model & Amplitude & $\mathrm{R}^{2}$ \\
\hline $\mathrm{V}_{\mathrm{N}}$ & 2.10 & 0.39 & $\mathrm{~N}=44.447+1.8664 * \mathrm{I}_{\mathrm{N}}$ & $-2.29<\mathrm{I}_{\mathrm{N}}<1.26$ & 0.187 \\
\hline$V_{\mathrm{p}}$ & -0.38 & 0.35 & $\mathrm{P}=3.597+0.1801^{\mathrm{ns}} \mathrm{I}_{\mathrm{P}}$ & $-2.39<\mathrm{I}_{\mathrm{P}}<1.97$ & 0.051 \\
\hline $\mathrm{V}_{\mathrm{K}}$ & 2.12 & 0.31 & $\mathrm{~K}=43.588-1.0936^{\mathrm{ns}} \mathrm{I}_{\mathrm{K}}$ & $-2.61<\mathrm{I}_{\mathrm{K}}<1.69$ & 0.023 \\
\hline $\mathrm{V}_{\mathrm{Ca}}$ & 1.37 & 0.41 & $\mathrm{Ca}=20.693+1.9317 * * \mathrm{I}_{\mathrm{Ca}}$ & $-2.14<\mathrm{I}_{\mathrm{Ca}}<2.23$ & 0.235 \\
\hline $\mathrm{V}_{\mathrm{Mg}}$ & -0.20 & 0.39 & $\mathrm{Mg}=4.2626+0.2196 * \mathrm{I}_{\mathrm{Mg}}$ & $-2.42<\mathrm{I}_{\mathrm{Mg}}<1.61$ & 0.130 \\
\hline $\mathrm{V}_{\mathrm{S}}$ & -0.88 & 0.46 & $\mathrm{~S}=2.2182+0.2195^{\mathrm{ns}} \mathrm{I}_{\mathrm{S}}$ & $-2.63<\mathrm{I}_{\mathrm{S}}<1.70$ & 0.082 \\
\hline $\mathrm{V}_{\mathrm{B}}$ & -2.20 & 0.31 & $\mathrm{~B}=58.244+1.7264 * \mathrm{I}_{\mathrm{B}}$ & $-2.62<\mathrm{I}_{\mathrm{B}}<1.66$ & 0.015 \\
\hline $\mathrm{V}_{\mathrm{Cu}}$ & -3.74 & 0.43 & $\mathrm{Cu}=13.523+6.4587 * * \mathrm{I}_{\mathrm{Cu}}$ & $-1.82<\mathrm{I}_{\mathrm{Cu}}<2.78$ & 0.616 \\
\hline$V_{M n}$ & -2.05 & 0.63 & $\mathrm{Mn}=63.775+50.44 * \mathrm{I}_{\mathrm{Mn}}+11.331 * \mathrm{I}_{\mathrm{Mn}}^{2}$ & $-1.98<\mathrm{I}_{\mathrm{Mn}}<1.70$ & 0.796 \\
\hline$V_{Z n}$ & -2.61 & 0.28 & $\mathrm{Zn}=33.626+9.945 * * \mathrm{I}_{\mathrm{Zn}}$ & $-1.66<\mathrm{I}_{\mathrm{Zn}}<1.91$ & 0.649 \\
\hline $\mathrm{G}$ & 0.56 & 0.23 & - & - & - \\
\hline \multirow{2}{*}{ Variable } & \multirow{2}{*}{ Mean } & \multirow{2}{*}{ Standard deviation } & \multicolumn{3}{|l|}{ Stage 2} \\
\hline & & & Mathematical model & Amplitude & $\mathrm{R}^{2}$ \\
\hline $\mathrm{V}_{\mathrm{N}}$ & 2.13 & 0.23 & $\mathrm{~N}=37.111-0.6142^{\mathrm{ns}} \mathrm{I}_{\mathrm{N}}$ & $-2.03<\mathrm{I}_{\mathrm{N}}<2.17$ & 0.025 \\
\hline $\mathrm{V}_{\mathrm{P}}$ & -0.47 & 0.29 & $\mathrm{P}=2.8189+0.4484 * * \mathrm{I}_{\mathrm{P}}$ & $-2.26<\mathrm{I}_{\mathrm{P}}<1.68$ & 0.250 \\
\hline $\mathrm{V}_{\mathrm{K}}$ & 2.35 & 0.27 & $\mathrm{~K}=45.753+1.0586^{\mathrm{ns}} \mathrm{I}_{\mathrm{K}}$ & $-2.21<\mathrm{I}_{\mathrm{K}}<2.17$ & 0.028 \\
\hline $\mathrm{V}_{\mathrm{Ca}}$ & 1.44 & 0.30 & $\mathrm{Ca}=18.547+1.5789 * * \mathrm{I}_{\mathrm{Ca}}$ & $-1.65<\mathrm{I}_{\mathrm{Ca}}<1.82$ & 0.202 \\
\hline $\mathrm{V}_{\mathrm{Mg}}$ & -0.17 & 0.27 & $\mathrm{Mg}=3.6772+0.1182^{\mathrm{ns}} \mathrm{I}_{\mathrm{Mg}}$ & $-2.38<\mathrm{I}_{\mathrm{Mg}}<1.73$ & 0.055 \\
\hline $\mathrm{V}_{\mathrm{s}}$ & -1.01 & 0.46 & $\mathrm{~S}=1.9787+0.25^{\mathrm{ns}} \mathrm{I}_{\mathrm{S}}$ & $-3.22<\mathrm{I}_{\mathrm{S}}<1.67$ & 0.106 \\
\hline $\mathrm{V}_{\mathrm{B}}$ & -2.20 & 0.31 & $\mathrm{~B}=48.882+3.3861 * * \mathrm{I}_{\mathrm{B}}$ & $-2.07<\mathrm{I}_{\mathrm{B}}<2.56$ & 0.189 \\
\hline $\mathrm{V}_{\mathrm{Cu}}$ & -3.67 & 0.54 & $\mathrm{Cu}=9.6996+9.0214 * * \mathrm{I}_{\mathrm{Cu}}+4.1764 * * \mathrm{I}_{\mathrm{Cu}}{ }^{2}$ & $-1.75<\mathrm{I}_{\mathrm{Cu}}<1.82$ & 0.903 \\
\hline $\mathrm{V}_{\mathrm{Mn}}$ & -2.01 & 0.68 & $\mathrm{Mn}=63.934+54.232 * * \mathrm{I}_{\mathrm{Mn}}+14.441 * * \mathrm{I}_{\mathrm{Mn}}^{2}$ & $-1.85<\mathrm{I}_{\mathrm{Mn}}<1.77$ & 0.901 \\
\hline $\mathrm{V}_{\mathrm{Zn}}$ & -2.58 & 0.73 & $\mathrm{Zn}=31.429+36.982 * * \mathrm{I}_{\mathrm{Zn}}+16.727 * * \mathrm{I}_{\mathrm{Zn}}{ }^{2}$ & $-2.26<\mathrm{I}_{\mathrm{Zn}}<1.84$ & 0.944 \\
\hline $\mathrm{G}$ & 0.45 & 0.12 & - & - & - \\
\hline \multirow{2}{*}{ Variable } & \multirow{2}{*}{ Mean } & \multirow{2}{*}{ Standard deviation } & \multicolumn{3}{|c|}{ Harvest time } \\
\hline & & & Mathematical model & Amplitude & $\mathrm{R}^{2}$ \\
\hline $\mathrm{V}_{\mathrm{N}}$ & 1.37 & 0.22 & $\mathrm{~N}=20.792+0.7017 * \mathrm{I}_{\mathrm{N}}$ & $-1.87<\mathrm{I}_{\mathrm{N}}<2.07$ & 0.072 \\
\hline$V_{p}$ & -1.21 & 0.31 & $\mathrm{P}=1.6181+0.3498 * * \mathrm{I}_{\mathrm{P}}$ & $-2.50<\mathrm{I}_{\mathrm{P}}<2.45$ & 0.508 \\
\hline $\mathrm{V}_{\mathrm{K}}$ & 2.23 & 0.32 & $\mathrm{~K}=50.64-11.034 * * \mathrm{I}_{\mathrm{K}}$ & $-2.71<\mathrm{I}_{\mathrm{K}}<1.94$ & 0.589 \\
\hline $\mathrm{V}_{\mathrm{Ca}}$ & 1.64 & 0.27 & $\mathrm{Ca}=27.158+2.667 * * \mathrm{I}_{\mathrm{Ca}}$ & $-1.84<\mathrm{I}_{\mathrm{Ca}}<2.95$ & 0.358 \\
\hline $\mathrm{V}_{\mathrm{Mg}}$ & -0.42 & 0.25 & $\mathrm{Mg}=3.5117+0.4097 * * \mathrm{I}_{\mathrm{Mg}}$ & $-2.15<\mathrm{I}_{\mathrm{Mg}}<2.39$ & 0.342 \\
\hline $\mathrm{V}_{\mathrm{S}}$ & -0.94 & 0.38 & $\mathrm{~S}=2.1457-0.0213^{\mathrm{ns}} \mathrm{I}_{\mathrm{S}}{ }^{\mathrm{N}}$ & $-2.39<\mathrm{I}_{\mathrm{S}}<2.54$ & 0.001 \\
\hline $\mathrm{V}_{\mathrm{B}}$ & -2.24 & 0.27 & $\mathrm{~B}=55.448+5.683 * * \mathrm{I}_{\mathrm{B}}$ & $-2.04<\mathrm{I}_{\mathrm{B}}<2.40$ & 0.382 \\
\hline $\mathrm{V}_{\mathrm{Cu}}$ & -1.91 & 0.73 & $\mathrm{Cu}=82.249+72.15 * * \mathrm{I}_{\mathrm{Cu}}+17.837 * * \mathrm{I}_{\mathrm{Cu}}{ }^{2}$ & $-2.79<\mathrm{I}_{\mathrm{Cu}}<1.67$ & 0.905 \\
\hline $\mathrm{V}_{\mathrm{Mn}}$ & -2.01 & 0.46 & $\mathrm{Mn}=79.309+41.175 * * \mathrm{I}_{\mathrm{Mn}}+9.3223 * * \mathrm{I}_{\mathrm{Mn}}^{2}$ & $-1.80<\mathrm{I}_{\mathrm{Mn}}^{\mathrm{Cu}}<2.13$ & 0.880 \\
\hline $\mathrm{V}_{\mathrm{Zn}}$ & -2.70 & 0.44 & $\mathrm{Zn}=41.796+21.868 * * I_{\mathrm{Zn}}$ & $-2.55<\mathrm{I}_{\mathrm{Zn}}<1.85$ & 0.860 \\
\hline $\mathrm{G}$ & 0.53 & 0.12 & - & - & - \\
\hline
\end{tabular}

${ }^{1}$ Yields greater than $91.1 \mathrm{t} \mathrm{ha}^{-1}, 90.6 \mathrm{t} \mathrm{ha}^{-1}$ and $87.8 \mathrm{tha}^{-1}$, respectively. $*$ and $* *$ : significant at $5 \%$ and $1 \%$, respectively, by the t-test. 
Table 3. Optimal content and optimal range values for shoot nutrient concentrations of the carrots grown in the Alto Paranaíba region generated by the CND method, at the three stages sampled, in comparison with the literature.

\begin{tabular}{lrrrrccccc}
\hline \multirow{2}{*}{ Nutrient } & \multicolumn{3}{c}{ Optimal content } & \multicolumn{3}{c}{ Optimal range } & \multicolumn{3}{c}{ Literature } \\
\cline { 2 - 9 } & Stage 1 & Stage 2 & Harvest & Stage 1 & Stage 2 & Harvest & Stage 1 & Stage 2 ${ }^{2}$ & Harvest $^{2}$ \\
\hline & & & & & $\mathrm{g} \mathrm{kg}^{-1}$ \\
$\mathrm{~N}$ & 44.4 & 37.1 & 20.8 & $43.2-45.7$ & $34.5-39.7$ & $20.3-21.3$ & - & $18.0-25.0$ & $15.0-25.0$ \\
$\mathrm{P}$ & 3.6 & 2.8 & 1.6 & $3.1-4.1$ & $2.5-3.1$ & $1.3-1.9$ & - & $2.0-4.0$ & $1.8-4.0$ \\
$\mathrm{~K}$ & 43.6 & 45.8 & 50.6 & $38.7-48.5$ & $41.5-50.0$ & $43.2-58.0$ & 60.0 & $20.0-40.0$ & $14.0-40.0$ \\
$\mathrm{Ca}$ & 20.7 & 18.5 & 27.2 & $19.4-22.0$ & $17.5-19.5$ & $25.4-28.9$ & 22.5 & $20.0-35.0$ & $10.0-15.0$ \\
$\mathrm{Mg}$ & 4.3 & 3.7 & 3.5 & $4.1-4.4$ & $3.3-4.0$ & $3.2-3.8$ & 3.5 & $2.0-5.0$ & $4.0-5.0$ \\
$\mathrm{~S}$ & 2.2 & 2.0 & 2.1 & $1.7-2.8$ & $1.5-2.4$ & $1.7-2.6$ & 4.0 & - & - \\
\hline & & & & & $\mathrm{mg} \mathrm{kg}-1$ & & & & \\
$\mathrm{~B}$ & 58.3 & 48.9 & 55.4 & $57.1-59.4$ & $46.6-51.1$ & $51.7-59.2$ & - & $20.0-40.0$ & $20.0-40.0$ \\
$\mathrm{Cu}$ & 13.5 & 9.7 & 82.2 & $9.2-17.8$ & $5.5-17.6$ & $42.1-138.3$ & - & $4.0-10.0$ & $4.0-10.0$ \\
$\mathrm{Mn}$ & 63.8 & 63.9 & 79.3 & $35.2-102.4$ & $34.2-106.5$ & $56.0-110.9$ & - & $30.0-60.0$ & $30.0-60.0$ \\
$\mathrm{Zn}$ & 33.6 & 31.4 & 41.8 & $27.0-40.3$ & $14.2-63.5$ & $27.2-56.4$ & - & $20.0-60.0$ & $20.0-60.0$ \\
\hline
\end{tabular}

${ }^{1}$ Optimal content according to Malavolta et al. (1997); ${ }^{2}$ optimal range according to Hanlon \& Hochmuth (2009).

The availability of Mn to plants may be inversely related to the soil $\mathrm{pH}$, where the $\mathrm{Mn}$ deficiency is most pronounced in areas where the $\mathrm{pH}$ is higher than 6.2 (Dezordi et al. 2016). The average $\mathrm{pH}$ of the soils sampled in the present

Table 4. Order of nutrient limitation calculated by the CND method at the three stages for carrot crops.

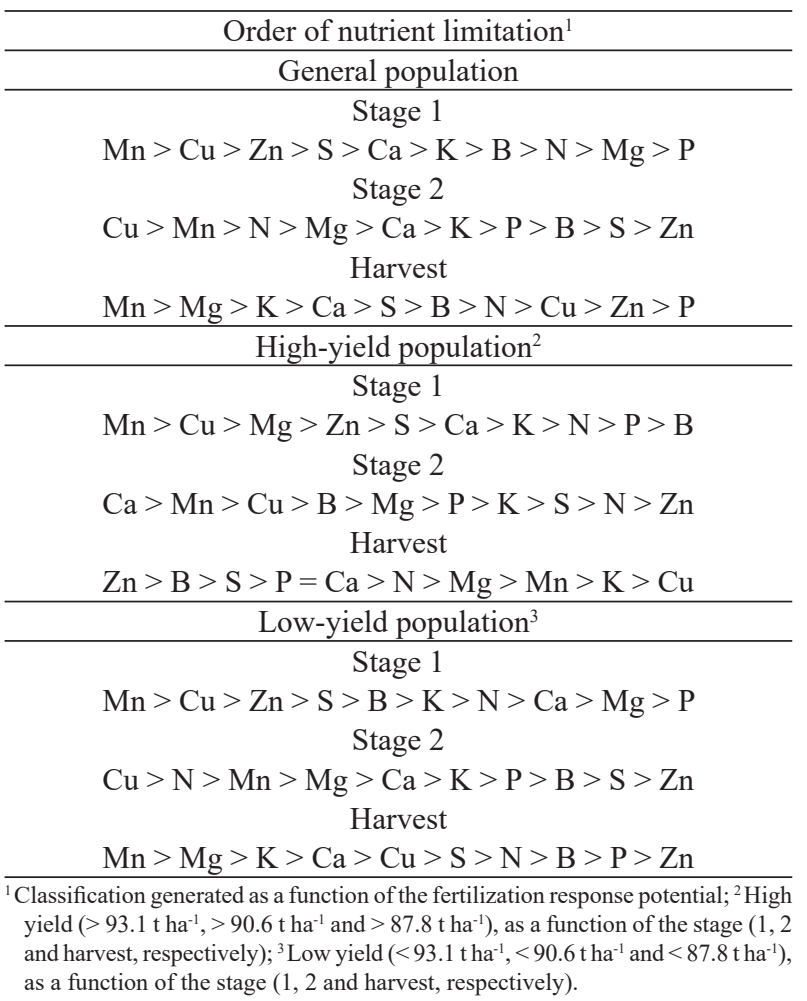

study is 6.3 (Table 1), evincing a deficiency of this nutrient (Borket 1991, Zanão Júnior et al. 2007). Furthermore, high amounts of $P$ at sowing time (average of $650 \mathrm{~kg} \mathrm{ha}^{-1}$ of $\mathrm{P}_{2} \mathrm{O}_{5}$ ) reduce the availability of $\mathrm{Mn}$, making it necessary to increase the nutrient supply for carrot crops (Gonçalves et al. 2011, Dezordi et al. 2016).

In general, $\mathrm{Zn}, \mathrm{B}$ and $\mathrm{P}$ were the least limiting nutrients for carrot crops, regardless of the sampling time. This may be due to the constant application of these nutrients in the soil and, in the case of $\mathrm{P}$, it may be owing to its high application rates in the cultivation areas (about $640 \mathrm{~kg} \mathrm{ha}^{-1}$ of $\mathrm{P}_{2} \mathrm{O}_{5}$ at sowing time).

With the use of the t-test, it was observed that the highest frequency of yield differences, in relation to the NL class, were at the stage 2 and at harvest time (Table 5). For N, K, Mg, Mn and Zn, these differences were higher at harvest time. This result suggests that the final stages are most adequate for sampling and foliar diagnosis in carrot crops, because a higher plant growth decreases the possibility of errors related to the nutrient concentration and dilution in dry matter (Maia 2012, Gonçalves et al. 2017).

Once the classes (LD, NL and LE) are defined, crops with a nutrient content in the limiting classes are expected to have lower yields than those appropriately nourished (Wadt et al. 2013). In contrast, the nutrients $\mathrm{N}, \mathrm{K}, \mathrm{Mg}, \mathrm{S}, \mathrm{Mn}$ and $\mathrm{Zn}$ showed significantly higher yields in the limiting classes (LD and LE). 
Table 5. Frequency of plots and average yield of the classes [limiting by deficiency (LD), non-limiting (NL) and limiting by excess (LE)] calculated by the CND method, as a function of the fertilization response potential, at the three stages sampled ${ }^{1}$.

\begin{tabular}{|c|c|c|c|c|c|c|c|}
\hline \multirow{2}{*}{ Nutrient } & \multirow{2}{*}{ Stage } & \multicolumn{3}{|c|}{ Nutritional status (\%) } & \multicolumn{3}{|c|}{ Yield $\left(\mathrm{t} \mathrm{ha}^{-1}\right)$} \\
\hline & & LD & $\mathrm{NL}$ & LE & LD & $\mathrm{NL}$ & $\mathrm{LE}$ \\
\hline \multirow{3}{*}{$\mathrm{N}$} & Stage 1 & 15.3 & 78.8 & 5.8 & 81.3 & 80.9 & 86.3 \\
\hline & Stage 2 & 20.0 & 70.0 & 10.0 & 77.6 & 77.6 & $87.2 *$ \\
\hline & Harvest & 10.5 & 64.4 & 2.0 & $89.4 * *$ & 74.7 & 71.8 \\
\hline \multirow{3}{*}{$\mathrm{P}$} & Stage 1 & 14.7 & 78.8 & 5.8 & 81.6 & 80.2 & 86.8 \\
\hline & Stage 2 & 20.7 & 66.4 & 12.8 & 79.2 & 78.5 & 76.6 \\
\hline & Harvest & 11.9 & 49.1 & 40.0 & 85.0 & 77.0 & $70.5^{*}$ \\
\hline \multirow{3}{*}{$\mathrm{K}$} & Stage 1 & 10.0 & 72.6 & 17.2 & 84.2 & 81.8 & 79.3 \\
\hline & Stage 2 & 18.3 & 57.3 & 24.4 & 80.6 & 79.3 & 76.4 \\
\hline & Harvest & 32.3 & 48.5 & 19.0 & 75.5 & 71.7 & $84.5 * *$ \\
\hline \multirow{3}{*}{$\mathrm{Ca}$} & Stage 1 & 22.9 & 58.3 & 18.7 & 85.8 & 80.3 & 78.8 \\
\hline & Stage 2 & 24.4 & 56.8 & 18.8 & 77.7 & 77.9 & 81.3 \\
\hline & Harvest & 28.5 & 50.0 & 21.4 & 75.6 & 77.6 & $69.8 *$ \\
\hline \multirow{3}{*}{$\mathrm{Mg}$} & Stage 1 & 18.1 & 66.4 & 15.3 & 78.8 & 80.7 & 87.0 \\
\hline & Stage 2 & 30.3 & 56.0 & 13.7 & $71.5^{* *}$ & 80.1 & 87.1 \\
\hline & Harvest & 35.6 & 58.5 & 5.8 & 73.2 & 74.4 & $95.7 * *$ \\
\hline \multirow{3}{*}{ S } & Stage 1 & 21.6 & 40.3 & 38.0 & 85.3 & 81.8 & 80.3 \\
\hline & Stage 2 & 15.3 & 59.5 & 25.2 & $86.4^{*}$ & 77.3 & 81.3 \\
\hline & Harvest & 14.5 & 59.3 & 26.0 & $79.3 *$ & 70.6 & 69.8 \\
\hline \multirow{3}{*}{ B } & Stage 1 & 12.1 & 67.1 & 20.7 & 85.4 & 82.3 & 76.9 \\
\hline & Stage 2 & 21.7 & 57.7 & 20.6 & 77.8 & 79.0 & 78.5 \\
\hline & Harvest & 9.8 & 81.9 & 8.3 & $83.1^{*}$ & 73.2 & 81.8 \\
\hline \multirow{3}{*}{$\mathrm{Cu}$} & Stage 1 & 32.8 & 41.2 & 26.0 & 80.0 & 80.8 & 82.4 \\
\hline & Stage 2 & 38.0 & 40.1 & 21.9 & 76.3 & 78.1 & 80.5 \\
\hline & Harvest & 16.4 & 59.4 & 24.1 & 72.6 & 74.1 & 77.5 \\
\hline \multirow{3}{*}{$\mathrm{Mn}$} & Stage 1 & 40.6 & 35.9 & 23.4 & 77.9 & 79.5 & 85.8 \\
\hline & Stage 2 & 33.5 & 39.9 & 26.6 & 77.4 & 75.7 & $84.0^{*}$ \\
\hline & Harvest & 41.6 & 37.0 & 21.3 & $66.9 * *$ & 78.3 & 83.2 \\
\hline \multirow{3}{*}{$\mathrm{Zn}$} & Stage 1 & 16.8 & 54.2 & 28.9 & 87.0 & 80.6 & 77.6 \\
\hline & Stage 2 & 12.3 & 37.1 & 50.6 & $94.2 * *$ & 81.5 & $72.1 * *$ \\
\hline & Harvest & 14.1 & 43.9 & 41.5 & $92.7 * *$ & 73.0 & 72.1 \\
\hline
\end{tabular}

* and ${ }^{* *}$ : different from the NL yield by the t-test at $5 \%$ and $1 \%$, respectively.

The highest yield (95.79 $\left.\mathrm{t} \mathrm{ha}^{-1}\right)$ was obtained when $\mathrm{Mg}$ was classified as limiting by excess (LE) (Table 5). Possibly, the adequate contents and ranges of this element in carrot leaves are superior to those obtained in this study. Thus, it is possible that the CND method has underestimated the optimal range in view of the general nutrient limitation, including that of the subpopulation classified as high yield.

The highest frequencies of plots in the nonlimiting class at the three sampled stages were for the nutrients $\mathrm{N}, \mathrm{Ca}, \mathrm{Mg}$ and $\mathrm{B}$ (Table 5). For one or more stages, the other nutrients presented higher frequencies of plots in the limiting classes (LD and LE), if compared to those in the non-limiting class. Among these, Mn stands out, evidencing its yield limitation, also observed in Table 4.
The definition of diagnostic indices during the carrot cycle (stage 1, stage 2 and harvest time) could be an alternative for correcting the fertilization method in the current crop. However, in general, the harvest stage had the highest frequencies of plots in the limiting classes, suggesting that this stage is the most adequate for the sampling and nutrient diagnosis of carrot crops. Moreover, Mn was the nutrient that most reduced carrot yield due to crop failure. Therefore, for Mn, the foliar diagnosis will only be effective in the correction of nutritional disorders in subsequent crops. Likewise, the high plant growth obtained in late sampling, such as at harvest time, minimizes the misunderstandings related to nutrient concentration and dilution in the plant dry matter (Maia 2012). 


\section{CONCLUSIONS}

1. At 70 days after sowing and at harvest time, $\mathrm{Mg}$ and $\mathrm{Mn}$ are the most limiting nutrients by deficiency, while $\mathrm{Zn}$ is the most limiting nutrient by excess at 70 days after sowing, and $\mathrm{P}$ and $\mathrm{Ca}$ are the most limiting nutrients by excess at harvest time;

2. To perform a nutrient diagnosis in carrot crops using the CND method, it is suggested that shoots be collected at harvest time. Therefore, an early nutrient diagnosis is not feasible and will only be effective in the correction of nutritional disorders in subsequent crops;

3. At harvest time, the appropriate contents of macronutrients $\left(\mathrm{g} \mathrm{kg}^{-1}\right)$ and micronutrients $\left(\mathrm{mg} \mathrm{kg}^{-1}\right)$ are: 20.3-21.3 for $\mathrm{N}$; 1.3-1.9 for P; 43.2-58.0 for $\mathrm{K}$; 25.4-28.9 for $\mathrm{Ca}$; 3.2-3.8 for $\mathrm{Mg}$; $1.7-2.6$ for $\mathrm{S} ;$ 51.7-59.2 for B; 42.1-138.3 for Fe; 56.0-110.9 for $\mathrm{Mn}$; and 27.2-56.4 for $\mathrm{Zn}$.

\section{REFERENCES}

ANUÁRIO Brasileiro de Hortaliças (ABH). 2015. Available at: $<$ http://www.anuarios.com.br/>. Access on: May 30, 2017.

AQUINO, R. F. B. A. et al. Nutrient demand by the carrot crop is influenced by the cultivar. Revista Brasileira de Ciência do Solo, v. 39, n. 2, p. 541-552, 2015.

BORKET, C. M. Manganês. In: FERREIRA, M. E.; CRUZ, M. C. P. (Eds.). Micronutrientes na agricultura. Piracicaba: Potafos, 1991. p. 173-188.

CAMACHO, M. A. et al. Faixas normais de nutrientes pelos métodos ChM, DRIS e CND e nível crítico pelo método de distribuição normal reduzida para laranjeirapera. Revista Brasileira de Ciência do Solo, v. 36, n. 1, p. 193-200, 2012.

CECÍlIO FILHO, A. B.; PEIXOTO, F. C. Acúmulo e exportação de nutrientes em cenoura 'Forto'. Revista Caatinga, v. 26, n. 1, p. 64-70, 2013.

DEZORDI, L. R. et al. Diagnostic methods to assess the nutritional status of the carrot crop. Revista Brasileira de Ciência do Solo, v. 40, e0140813, 2016.

DEZORDI, L. R. et al. Nutrient recommendation model for carrot crop-ferticalc carrot. Revista Brasileira de Ciência do Solo, v. 39, n. 6, p. 1714-1722, 2015.

DEZORDI, L. R. Modelagem da demanda nutricional e indices diagnósticos foliares para a cultura da cenoura. 2014. 73 f. Dissertação (Mestrado em Agronomia) Universidade Federal de Viçosa, Rio Paranaíba, 2014.
FAGERIA, N. K.; BALIGAR, V. C.; JONES, C. A. Growth and mineral nutrition of field crops. New York: CRC Press, 2011.

FARIAS, D. R. et al. Fósforo em solos representativos do estado da Paraíba: I - isotermas de adsorção e medidas do fator capacidade de fósforo. Revista Brasileira de Ciência do Solo, v. 33, n. 3, p. 623-632, 2009.

GONÇALVES, F. A. R. et al. DRIS indices in three phenological stages of the carrot crop. Pesquisa Agropecuária Tropical, v. 47, n. 1, p. 31-40, 2017.

GONÇALVES, G. K. et al. Relação entre óxidos de ferro e de manganês e a sorção de fósforo em solos no Rio Grande do Sul. Revista Brasileira de Ciência do Solo, v. 35, n. 5, p. 1633-1639, 2011.

HANLON, E. A.; HOCHMUTH, G. J. Carrot. In: CAMPBELL, C. R. Reference sufficiency ranges for plant analysis in the southern region of the United States. Raleigh: North Carolina Department of Agriculture, 2009. p. 63-64.

KOTTEK, M. et al. World map of the Köppen-Geiger climate classification updated. Meteorology Zeitschrift, v. 15 , n. 3, p. 259-263, 2006.

MAIA, C. E. Época de amostragem foliar para diagnóstico nutricional em bananeira. Revista Brasileira de Ciência do Solo, v. 36, n. 3, p. 859-864, 2012.

MALAVOLTA, E.; VITTI, G. C.; OLIVEIRA, S. A. Avaliação do estado nutricional das plantas: princípios e aplicações. 2. ed. Piracicaba: Associação Brasileira para Pesquisa da Potassa e do Fosfato, 1997.

MAROUELLI, W. A.; OLIVEIRA, R. A.; SILVA, W. L. C. Irrigação na cultura da cenoura. Brasília, DF: Embrapa Hortaliças, 2007.

PARENT, L. E. Diagnosis of the nutrient compositional space of fruit crops. Revista Brasileira de Fruticultura, v. 33, n. 1, p. 321-334, 2011.

PARENT, L. E.; DAFIR, M. A. Theoretical concept of compositional nutrient diagnosis. Journal of the American Society for Horticultural Science, v. 117, n. 2, p. 239-242, 1992.

PARTELLI, F. L. et al. Avaliação nutricional de feijoeiro irrigado pelos métodos CND, DRIS e faixas de suficiência. Revista Brasileira de Ciência do Solo, v. 38, n. 3, p. 858866, 2014.

PEGORARO, R. F. et al. Fluxo difusivo de micronutrientes catiônicos afetado pelo tipo, dose e época de incorporação de adubos verdes ao solo. Revista Brasileira de Ciência do Solo, v. 30, n. 6, p. 997-1006, 2006.

SANTOS, E. F. et al. Faixas normais de nutrientes em canade-açúcar pelos métodos ChM, DRIS e CND e nível crítico 
pela distribuição normal reduzida. Revista Brasileira de Ciência do Solo, v. 37, n. 3, p. 1651-1658, 2013.

SERRA, A. P. et al. Desenvolvimento de normas DRIS e CND e avaliação do estado nutricional da cultura do algodoeiro. Revista Brasileira de Ciência do Solo, v. 34, n. 1, p. 97-104, 2010.

SINGH, D. P. et al. Impact of boron, calcium and genetic factors on vitamin C, carotenoids, phenolic acids, anthocyanins and antioxidant capacity of carrots (Daucus carota L.). Food Chemistry, v. 132, n. 3, p. 1161-1170, 2012.

STATISTICALANALYSIS SYSTEM(SAS) INSTITUTE. SAS: user's guide, version 8.2. Cary: SAS Institute, 1999.

TOMIO, D. B. et al. Antecipação da diagnose foliar em arroz de sequeiro. Pesquisa Agropecuária Brasileira, v. 50, n. 3, p. 250-258, 2015.

UNITED STATES OF AMERICA (USA). United States Department of Agriculture. Keys to soil taxonomy. 12. ed. Washington, DC: USDA, 2014.

URANO, E. O. M. et al. Avaliação do estado nutricional da soja. Pesquisa Agropecuária Brasileira, v. 41, n. 9, p. 1421-1428, 2006.
URANO, E. O. M. et al. Determinação de teores ótimos de nutrientes em soja pelos métodos chance matemática, sistema integrado de diagnose e recomendação e diagnose da composição nutricional. Revista Brasileira de Ciência do Solo, v. 31, n. 1, p. 63-72, 2007.

WADT, P. G. S. et al. Padrões nutricionais para lavouras arrozeiras irrigadas por inundação pelos métodos da CND e chance matemática. Revista Brasileira de Ciência do Solo, v. 37, n. 1, p. 145-156, 2013.

WADT, P. G. S. et al. Três métodos de cálculo do DRIS para avaliar o potencial de resposta à adubação de árvores de eucalipto. Revista Brasileira de Ciência do Solo, v. 22, n. 4, p. 661-666, 1998.

WADT, P. G. S. Relationships between soil class and nutritional status of coffee plantations. Revista Brasileira de Ciência do Solo, v. 29, n. 2, p. 227-234, 2005.

ZANÃO JÚNIOR, L. A.; LANA, R. M. Q.; GUIMARÃES, E. C. Variabilidade espacial do $\mathrm{pH}$, teores de matéria orgânica e micronutrientes em profundidades de amostragem num Latossolo Vermelho sob semeadura direta. Ciência Rural, v. 37, n. 4, p. 1000-1007, 2007. 